\title{
Particle aggregation during a diatom bloom. II. Biological aspects
}

\author{
Ulf Riebesell
}

\begin{abstract}
Alfred Wegener Institute for Polar and Marine Research, Columbusstr., D-2850 Bremerhaven, Germany
\end{abstract}
\begin{abstract}
For a 6 wk period covering the time before, during, and after the phytoplankton spring bloom, macroscopic aggregates ( $\geq 0.5 \mathrm{~mm}$ diameter) were repeatedly collected and water column properties simultaneously measured at a fixed station in the Southern North Sea. Distinct changes in aggregate structure and composition were observed during the study. Predominantly detrital aggregates during the early phase of the study were followed by diatom-dominated algal flocs around the peak of the bloom. Mucus-rich aggregates containing both algal and detrital components and with large numbers of attached bacteria dominated the post-bloom interval. The phytoplankton succession within the aggregates closely reflected the succession in the water column with a time delay of a few days. Algal flocculation did not occur as a simultaneous aggregation of the entire phytoplankton community, but as a successional aggregation of selected diatom species. Although the concentrations of inorganic nutrients diminished considerably during the development of the phytoplankton bloom, the termination of the bloom appeared to be mostly controlled by physical coagulation processes. The importance of biologically-controlled factors for physical coagulation is discussed.
\end{abstract}

\section{INTRODUCTION}

Mass flocculation during diatom blooms as predicted by Smetacek (1985) has since been documented both in the field (Kranck \& Milligan 1988, Alldredge \& Gotschalk 1989) and in mesocosm experiments (Riebesell 1989). Simultaneous aggregation of an entire phytoplankton community and its subsequent sedimentation was shown to occur on time-scales as short as $24 \mathrm{~h}$ (Alldredge \& Gotschalk 1989). Despite the broad evidence for aggregate formation in association with phytoplankton blooms, both the causes and regulating mechanisms are not well understood. Flocculation and subsequent sedimentation of diatoms has been considered to be an integral part of diatom life history (Smetacek 1985, von Bodungen et al. 1986). Nutrient depletion was hypothesized to induce phytoplankton aggregation due to an assumed increase in stickiness of nutrient-depleted cells (Smetacek 1985, Logan \& Alldredge 1989). A relationship between cell stickiness and the nutritional status of phytoplankton cultures was demonstrated by Kiorboe et al. (1990). The role of bacteria in bonding particles together in aggregates has been emphasized by Kranck \& Milligan (1980) and Biddanda (1985). While bacterial bonding and the variation of algal stickiness in response to nutrient depletion would imply that flocculation is largely controlled by biological factors, Jackson (1990), assuming a constant stickiness, proposed that physical processes alone could determine the time and extent of algal aggregation. Based on a physical coagulation model, Jackson predicted that the rate of aggregation strongly depends on algal concentration. Above a critical maximum concentration, physical coagulation would become the dominant force leading to a rapid flocculation of a large portion of the algal biomass (Jackson 1990). The extent to which algal flocculation is determined by either physically or biologically controlled processes remains to be established. Presumably, a combination of both types of processes will drive aggregation under natural conditions.

Previous field investigations of algal flocculation have focussed on the aggregation event as such. The object of this study was to investigate particle aggregation over a period covering the development and decline of a phytoplankton bloom, and to relate aggregation processes both to the state of the phytoplankton community and to the prevailing physico-chemical conditions of the environment.

\section{MATERIAL AND METHODS}

Sampling procedure. Investigations were conducted in the German Bight (North Sea) from 18 April to 1 June, 1989 at one station, which was sampled 10 
times at intervals ranging between 3 and $11 \mathrm{~d}$. Nutrient, chlorophyll $a_{1}$ and phaeopigment concentrations, particulate organic carbon and nitrogen content, bacterio- and phytoplankton abundance, and the phytoplankton species composition were determined on seawater samples taken with 10 I Niskin bottles from 1, 10 , 20 , and $30 \mathrm{~m}$ depths

During each station, SCUBA divers hand-collected 20 to 40 individual aggregates at approximately $10 \mathrm{~m}$ depth in $1 \mathrm{ml}$ polypropylene syringes. For sampling convenience, the largest aggregates present at the time of collection, which were generally $>0.5 \mathrm{~mm}$ in diameter, were chosen. In order to avoid destruction of the aggregates during sampling, the forward ends of the syringes were cut off and the resulting open cylinder was sealed with a serum stopper immediately after sampling. In the laboratory, only those aggregate samples were used for further analysis which still consisted of a single, intact aggregate. An attempt was also made to sample surrounding water free of aggregates. However, due to the high concentration of minute aggregated particulate material during most of the study period, in situ sampling of aggregate-free surrounding water was not possible.

Laboratory analyses. Dissolved inorganic nutrient concentrations ( $\mathrm{Si}, \mathrm{NO}_{3}^{-}, \mathrm{NH}_{4}^{+}, \mathrm{PO}_{4}^{-4}$ ) were analysed on a Technicon Autoanalyser II using standard methods. Nutrient samples were fixed with $\mathrm{HgCl}_{2}$ (final concentration $0.01 \%$ ) immediately after collection. For the determination of chlorophyll $a$ and phaeopigment concentrations, $500 \mathrm{ml}$ of sampling water were filtered onto $25 \mathrm{~mm}$ Whatman GF/C glass fiber filters. After extraction in $90 \%$ acetone (filters were homogenized with glass beads), the samples were analysed using standard fluorometric methods (Parsons et al. 1984). For the determination of the particulate organic carbon (POC) and nitrogen (PON) content, 11 of sampling water was filtered through precombusted, $25 \mathrm{~mm}$ Whatman GF/C glass fiber filters and stored at $-30{ }^{\circ} \mathrm{C}$ until analysis. After the filters were treated with a drop of $1 \mathrm{~N} \mathrm{HCl}$ to remove inorganic carbon, POC/PON were measured on a Carlo Erba $1500 \mathrm{CHN}$ Analyser.

For particle aggregates, the chlorophyll a and phaeopigment content as well as the POC/PON content were analysed using the same methods as described above. For each sampling date, the chlorophyll $a$ and phaeopigment content of 6 individual aggregates were measured. Two replicate sets of 3 to 6 aggregates (depending on aggregate size) were used for the determination of POC/PON. Aggregates were filtered with a minimum of surrounding water (generally less than $0.2 \mathrm{ml}$ per aggregate).

Light microscopic analyses of both seawater samples and particle aggregates were carried out qualitatively on live material within $5 \mathrm{~h}$ after collection and recorded on video tape. Enumeration of organisms and fecal pellets was performed on water samples preserved in Lugol's iodine solution using the inverted microscope method of Utermöhl (1958). Microscopic counting of the organisms and fecal pellets contained in 5 individual aggregates from each sampling date was conducted on intact aggregates under the inverted microscope. In cases where aggregates were too dense to be analysed in their existing form, they were gently squeezed between slide and cover-slip. For the purpose of scanning electron microscopy (SEM), individual aggregates were dehydrated through an alcohol series, criticalpoint-dried in liquid $\mathrm{CO}_{2}$, and platin-palladium coated. They were then examined on an ISI D 130 SEM.

For bacterial enumerations, $1 \mathrm{ml}$ of sample water from each depth and 3 individual aggregates from each sampling date fixed in $2 \%$ glutaraldehyde were filtered onto $0.2 \mu \mathrm{m}$ Irgalan black-stained Nuclepore filters. After staining with DAPI or acridine orange, the abundance of free bacteria in the water samples and of bacteria attached to the outer surface of aggregates was determined using an epifluorescence microscope (Hobbie et al. 1977). Numbers of bacteria attached to the aggregate surface were determined by focussing on the outer aggregate surface and counting attached bacteria in this thin layer in 30 random fields on each aggregate. Since bacterial abundance in the water column was determined as number per volume, and in aggregates as number per surface area of aggregate, a comparison in absolute numbers is not possible for this data set. The evaluation of the data will therefore be confined to a relative comparison.

Enrichment factors were calculated by dividing the concentration of a given organism in aggregates (number per volume), by its concentration in the water column. The approximate aggregate volume was estimated by sizing the intact aggregates under an inverted microscope. Since surrounding water samples (i.e. water free of aggregates) could not be collected, regular water column samples containing both freely suspended cells and aggregated material disrupted during sampling and handling were used. Therefore, the enrichment factors presented herein underestimate the actual enrichment of organisms in aggregates relative to the aggregate-free water. Relative enrichment factors of individual diatom species were obtained by dividing the relative abundance of a given species in aggregates (percent of total diatom cell number), by its relative abundance in the water column.

\section{RESULTS}

Inorganic nutrient concentrations recorded over the period of investigation (Fig. 1) were within the range of 


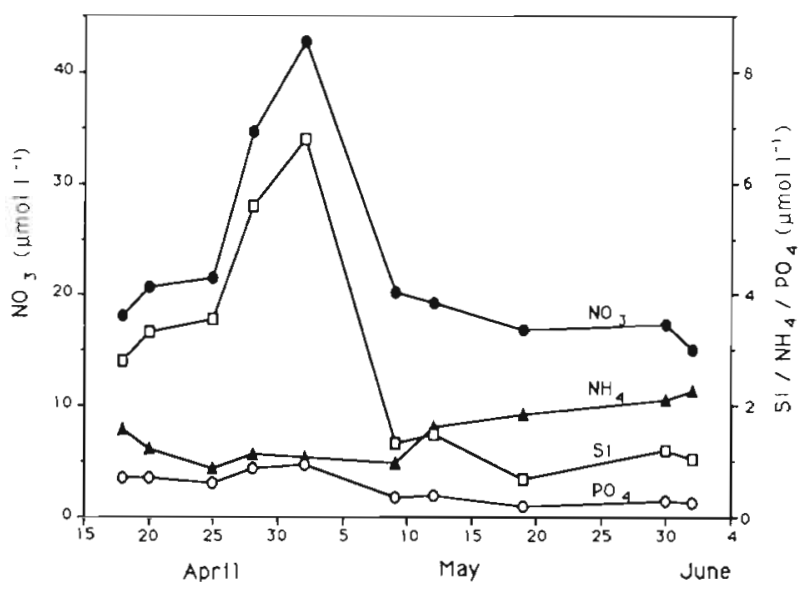

Fig. 1. Concentrations of the inorganic nutrients nitrate, phosphate, ammonium, and silicate on station at $10 \mathrm{~m}$ depth vs time

concentrations typically measured in this area during the spring (Radach et al. 1990). An increase in nutrient concentrations during the last week of April concomitant to an increase in surface salinity (not presented here), was caused by the horizontal advection of water from the outer North Sea resulting from a period of consistent northwesterly winds. A rapid decrease in nutrient concentrations during the first week of May was related to the development of the phytoplyankton spring bloom. While the post-bloom nitrate concentration remained at approximately the same level as the pre-bloom concentration, both phosphate and silica showed significantly lower values after the decline of the bloom. The ammonium concentration increased slightly over the study period.
The development of the phytoplankton cell numbers (Fig. 2) shows a similar trend to that of the chlorophyll a concentrations depicted in Fig. 1 of the companion manuscript (Riebesell 1991). A first bloom during the last week of April was dominated by the prymnesiophyte Phaeocystis sp., which comprised up to $55 \%$ of the cell numbers. The sudden disappearance of the Phaeocystis bloom was attributed to horizontal advection from the outer North Sea (see above). During a second bloom in the first half of May, diatoms (including Thalassionema nitzschioides, Asterionella glacialis, Thalassiosira spp., Chaetoceros spp., Nitzschia sp., and Skeletonema costatum, in order of abundance) were the most prominent group, comprising up to $64 \%$ of the cells. After the decline of the bloom, the phytoplankton consisted almost entirely of naked flagellates.

A comparison of the biochemical composition of particulate material suspended in the water column (including both aggregated and non-aggregated matter) with that of the material concentrated in aggregates is presented in Table 1 . Since aggregate sampling by divers was biased towards larger aggregate sizes, the biochemical composition determined on these samples may not be representative of the bulk of aggregated material. Over the entire period of investigation, the POC/PON ratio of the aggregated material was significantly higher than that of the total suspended material. Depending on the size of aggregates present on the day of collection, the mean organic carbon and nitrogen content in the aggregates varied from 0.3 to $21.9 \mu \mathrm{g} \mathrm{C}$ aggregate ${ }^{-1}$ and 0.04 to $3.0 \mu \mathrm{g} \mathrm{N}$ aggregate $^{-1}$. The percentage chlorophyll a of the chlorophyll a + phaeopigment concentration in the aggregates was consistently lower than that in the



Fig. 2. Phytoplankton cell numbers of the dominant species and algal groups in the upper mixed layer over the course of the study (cumulative plotting) 
Table 1. $\mathrm{C} / \mathrm{N}$ ratios (by weight) and percentage chlorophyll a of chlorophyll a + phaeopigment concentration of the particulate material suspended in the water column and agglomerated in particle aggregates $( \pm 1 \mathrm{SD})_{i}$ water column values represent averages of 0 and $10 \mathrm{~m}$ samples, aggregates were collected at ca $10 \mathrm{~m}$ depth. ND: not determined

\begin{tabular}{|c|c|c|c|c|}
\hline \multirow{2}{*}{$\begin{array}{l}\text { Date } \\
(1989)\end{array}$} & \multicolumn{2}{|c|}{$\mathrm{C} / \mathrm{N}$} & \multicolumn{2}{|c|}{ Chl a/(chl a + phaeopigments $) \times 100$} \\
\hline & $\begin{array}{l}\text { Water column } \\
\qquad \mathrm{n}=2\end{array}$ & $\begin{array}{c}\text { Aggregates } \\
n=5\end{array}$ & $\begin{array}{l}\text { Water column } \\
\qquad \mathrm{n}=2\end{array}$ & $\begin{array}{c}\text { Aggregates } \\
n=5\end{array}$ \\
\hline $21 \mathrm{Apr}$ & $5.56( \pm 0.31)$ & ND & $89.7( \pm 0.5)$ & $83.8( \pm 2.9)$ \\
\hline $25 \mathrm{Apr}$ & $5.95( \pm 0.03)$ & $8.94( \pm 0.57)$ & $90.3( \pm 2.5)$ & $77.9( \pm 4.2)$ \\
\hline $28 \mathrm{Apr}$ & $5.76( \pm 0.11)$ & $6.57( \pm 0.51)$ & $94.8( \pm 1.3)$ & $79.9( \pm 9.3)$ \\
\hline 2 May & $5.86( \pm 0.17)$ & $6.70( \pm 0.05)$ & $77.0( \pm 3.0)$ & ND \\
\hline 9 May & $6.60( \pm 0.26)$ & ND & $73.4( \pm 1.1)$ & $47.4( \pm 6.9)$ \\
\hline $12 \mathrm{May}$ & $6.64( \pm 0.10)$ & $7.44( \pm 0.58)$ & $71.1( \pm 3.6)$ & $48.9( \pm 3.7)$ \\
\hline 19 May & $5.86( \pm 0.02)$ & $6.31( \pm 0.18)$ & $78.4( \pm 0.1)$ & $61.8( \pm 8.5)$ \\
\hline $1 \mathrm{Jun}$ & $5.31( \pm 0.33)$ & $7.12( \pm 0.52)$ & $72.9( \pm 1.2)$ & $21.6( \pm 4.5)$ \\
\hline
\end{tabular}

Table 2. Absolute enrichment of different components in aggregates relative to bulk seawater collected at the same depth; as bulk seawater samples contained both freely suspended and aggregated material, enrichment factors represent underestimates. NF: not found in aggregates

\begin{tabular}{|c|c|c|c|c|c|c|c|}
\hline \multirow{2}{*}{ Group } & \multicolumn{7}{|c|}{ Date } \\
\hline & $25 \mathrm{Apr}$ & $28 \mathrm{Apr}$ & 2 May & 9 May & 12 May & 19 May & $1 \mathrm{Jum}$ \\
\hline Diatorns & 6770 & 3280 & 930 & 490 & 1260 & 1760 & 26500 \\
\hline Phaeocystis sp. & 1650 & NF & 70 & 520 & 320 & 81.0 & NF \\
\hline Dinoflagellates & NF & 130 & NF & NF & NF & 240 & 1740 \\
\hline Protozoa & 410 & 180 & NF & 7 & 2 & $N F$ & 50 \\
\hline Fecal pellets & 320 & 1280 & 380 & 210 & 5170 & 3200 & 92800 \\
\hline
\end{tabular}

water column (Table 1). Whereas the percentage chlorophyll a in both total suspended matter and aggregates generally decreased over the course of the study, the decline was much more pronounced in the case of the aggregates. The mean absolute chlorophyll $a$ and phaeopigment content in aggregates varied from 2.5 to $35.4 \mathrm{ng}$ chl a aggregate ${ }^{-1}$ and 1.3 to $19.8 \mathrm{ng}$ phaeo aggregate ${ }^{-1}$, again mostly depending on aggregate size present on the respective day of collection.

All organisms identified in water column samples were also found associated with aggregates. However, their concentration (numbers per volume) was highly enriched in the aggregates. The absolute enrichment factors of 5 different groups (including fecal pellets) are presented in Table 2. With the exception of one sampling day (9 May), diatoms consistently showed the highest enrichment factors. In general, a trend could be seen with decreasing diatom enrichment during the build-up of the bloom, and increasing enrichment following the peak of the bloom. Rather than being caused by an absolute increase in the number of diatoms in aggregates, this enrichment effect was due to the relatively lower cell numbers in the water column before and after the bloom. In contrast to diatoms, relatively low enrichment factors were found for gelatinous colonies of Phaeocystis sp.. In the case of dinoflagellates and protozoans, an even lower enrichment factor was observed and at certain times, these groups were not encountered in aggregates at all. Fecal pellets became highly enriched in aggregates subsequent to the decline of the phytoplankton bloom.

Comparing the relative enrichment of the dominant diatom species in flocs with their absolute abundance in the water column, reveals a similar pattern for the different species (Fig. 3). The highest relative enrichment of 5 diatom species in aggregates occurred a few days after their respective maximum abundance in the water column. The timing of the enrichment peak differed among the different species, so that a sequence of species-dominated aggregates emerged. While Skeletonema costatum and Nitzschia sp. were concentrated in aggregates early in the bloom, a shift of Asterionella glacialis and Thalassionema nitzschioides from the water column into aggregates occurred during the decline of the bloom.

Distinct differences among the species were also found with respect to their degree of maximum enrichment in aggregates. While for Asterionella glacialis and Coscinodiscus sp. values $>15$ and $>20$ were calculated, the other 3 species did not attain a relative enrichment of more than 7. Two extreme cases were found for Skeletonema costatum and Nitzschia sp.; 

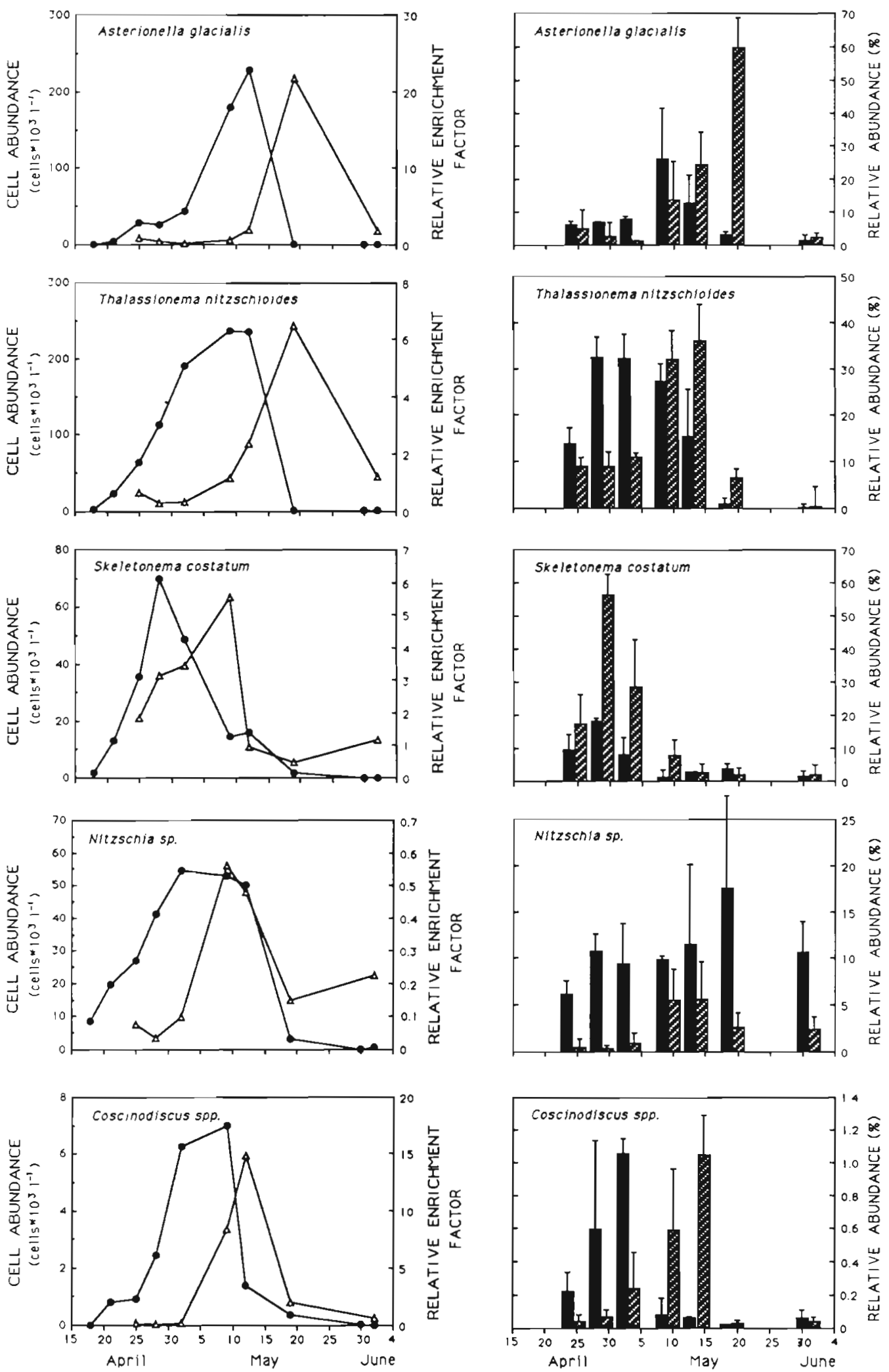

Fig. 3. Left: Absolute cell abundance ( $\bullet$ ) and relative enrichment in aggregates $(\Delta)$ of 5 different species vs time at $10 \mathrm{~m}$ depth Relative enrichment is the quotient of species abundance in the water column and in aggregates as shown at right. Right: Relative species abundance in the water column (solid bars) and in aggregates (hatched bars) vs time at $10 \mathrm{~m}$ depth. Error bars indicate 1 standard deviation $(\mathrm{n}=5)$ 
with one exception on 19 May, S. costatum showed a consistently higher relative abundance in aggregates than in the water column (enrichment factor $>1$ ). Nitzschia sp. on the other hand, was always relatively more abundant in the water column than in aggregates (enrichment factor $<1$ ).

Bacterial numbers in the water column increased rapidly during the development of the phytoplankton bloom and reached a maximum value a few days after the peak of the bloom (Fig. 4). A similar trend, although at a slower rate of increase, was observed for the abundance of bacteria attached to aggregates. Over the course of the study, a 3 - to 4 -fold increase in bacterial numbers was recorded both in the water (per unit volume of seawater), and on the aggregates (per unit surface area of aggregate). The bacterial distribution on aggregates became increasingly patchy with time. In contrast to the decline in the total number of bacteria during the latter part of the study, bacterial colonisation on aggregates continued to increase until the end of the investigation.

The structure and composition of particle aggregates was further examined using SEM. Different types of aggregates were encountered before, during, and after the bloom. The relatively small and densely-packed aggregates found before and, to a lesser extent, during the bloom, consisted mainly of unidentified detrital material with only a few phytoplankton cells attached to the outer surface (Fig. 5a). During the development of the bloom, chains of living diatoms comprised the bulk of material in aggregates. Cell chains, in some cases consisting of up to several hundred cells, often served as the aggregate matrix to which other particles, detritus, fecal pellets, empty frustules etc. were attached (Fig. 5b to d). During the decline of the bloom,

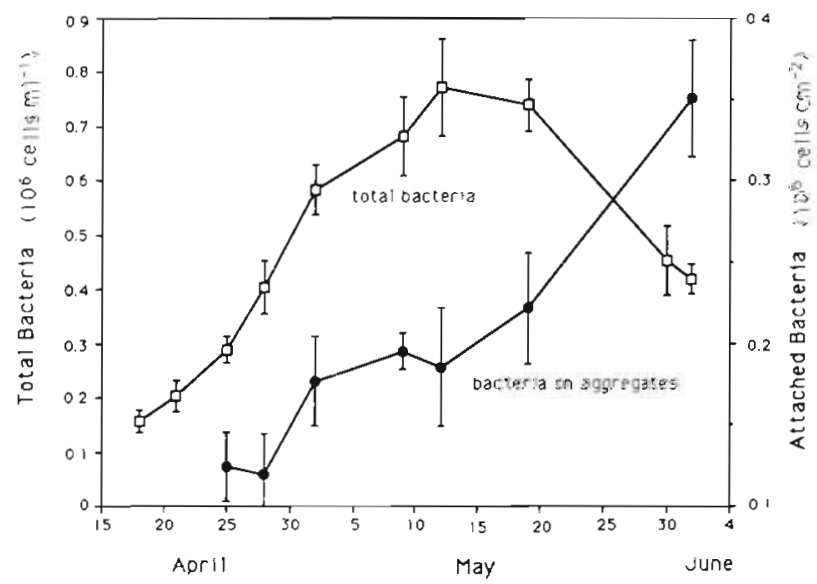

Fig. 4. Bacterial numbers in the water column (in $10^{6}$ cells $\mathrm{ml}^{-1}$ ) and attached to aggregates (in $10^{6}$ cells $\mathrm{cm}^{-2}$ aggregate surface area), both at $10 \mathrm{~m}$ depth. Error bars indicate 1 standard deviation ( $\mathrm{n}=2$ for total bacterial numbers, $\mathrm{n}=4$ for bacterial numbers on aggregates) many aggregates were characterized by a matrix of amorphous mucus which was densely colonized by bacteria and in which detrital particles including an increasing number of fecal pellets and empty diatom frustules were embedded (Fig. 5e, f). Under the epifluorescence microscope, large numbers of autotrophic nano-flagellates in the size range of 2 to $10 \mu \mathrm{m}$ were found within the mucous matrix.

\section{DISCUSSION}

This investigation was the first attempt to repeatedly sample macroscopic aggregates over a timespan covering the period before, during, and after a phytoplankton bloom and to identify changes in the structure and composition of the aggregates over this period. A distinct succession in aggregate composition, which closely reflected the succession of particulate material in the water column, was observed during the study.

Before the onset of the bloom, small ( $\leq 0.5 \mathrm{~mm}$ ) aggregates largely consisting of detrital particles were abundant. In many cases, diatoms were attached by simply sticking onto the outer surface of the detrital aggregates (Fig. 5a). An important source of detritus for these aggregates appeared to be resuspended material, which was introduced to the upper layer by strong mixing of the water column during winter and early spring storms. By the time of the peak of the diatom bloom, a large amount of the resuspended material had already been lost from the upper layer, possibly due to sedimentation of particle aggregates. As demonstrated by Peinert et al. (1982), the calm conditions necessary for bloom initiation also result in sedimentation of winter-resuspended matter. Long chains of living diatoms entangled in each other formed the matrix for the somewhat larger aggregates $(\leq 1 \mathrm{~mm}$ ) collected during this period (Fig. $5 \mathrm{~b}$ to d). In most aggregates, detrital and inorganic material was found attached to the diatom flocs. The majority of aggregates collected after the decline of the bloom were characterized by a complex matrix of mucus-like material with amorphous detritus, fecal pellets, and diatom frustules embedded in it (Fig. 5 e, f).

Dissolved organic carbon (DOC) in the water column, which commonly increases in concentration following the decline of a phytoplankton bloom (Degens \& Ittekkot 1984), may represent the source of the amorphous mucous material found to be an important component in aggregates during the decline of the bloom. The crucial role of mucus as a carrier and binding agent in pelagic systems was emphasized by Smetacek \& Pollehne (1986). As demonstrated by Kepkay \& Johnson (1988), surface coagulation onto bubbles in combination with a rapid development of a 

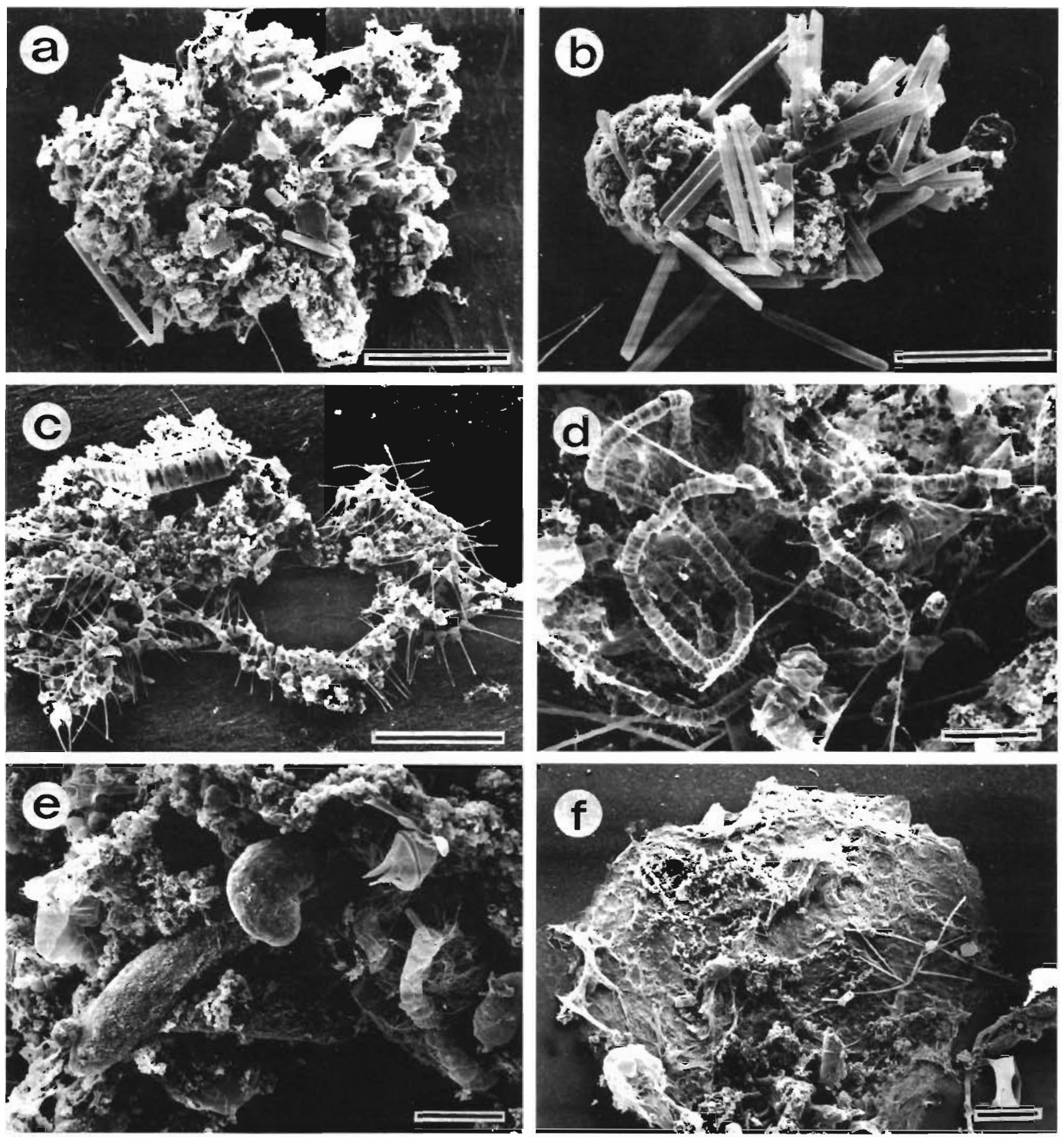

Fig. 5. SEM micrographs of aggregates typical for different periods during the study. (a) Densely-packed detrital aggregate with only a few phytoplankton cells attached to the outer surface, collected on 25 April before the phytoplankton bloom. (b) Aggregate largely consisting of cells of the diatom Thalassionema nitzschioides, collected 2 May during the build-up of the bloom. (c) Aggregate typical for the peak of the bloom, in which diatoms (here dominated by Asterionella glacialis) served as the aggregate matrix; 9 May. (d) Cell-chain of the diatom Thalassiosira sp. entangled in an aggregate, illustrating the potentially large effective size of chain-forming diatoms; long hair-like chitan fibers extending from each cell further increase the effective size; $12 \mathrm{May}$. (e) Detail of a large detrital aggregate with fecal pellets and different algae attached, typical of the post-bloom period; 19 May. (f) Amorphous aggregate consisting of a slime matrix with numerous detrital particles attached; 1 June. Scale bars $=50 \mu \mathrm{m}$ in $(\mathrm{a})$, (b), 
transient microbial community can effectively transfer DOC into particulate organic carbon. Biddanda (1985) reported that for de novo particle synthesis from DOC, the presence of active bacteria is a prerequisite. In fact, the total number of bacteria rapidly increased over the phytoplankton bloom period (Fig. 4). In particular, the potential importance of bacteria for aggregate formation during the decline of the bloom was indicated by the rapid increase in bacterial numbers on aggregates during this period. The strong patchiness in the distribution of attached bacteria on aggregates could indicate the difference in age of different parts of the aggregates. High concentrations of DOC and high bacterial activity may have favoured the formation of exceptionally large aggregates (up to $5 \mathrm{~cm}$ in longest dimension) during the decline of the bloom (see Riebesell 1991). While it is still not clear if bacteria are essential for the initial process of coagulation, they can certainly play a critical role in increasing particle stickiness and in bonding particles together within aggregates (Kranck \& Milligan 1980, Biddanda 1985).

In general, aggregates were always enriched in detrital material in comparison to the total suspended matter, as indicated by consistently higher $\mathrm{C} / \mathrm{N}$ ratios and phaeopigment contents (Table 1). While resuspended material may constitute the main portion of the detrital pool, especially during the initial part of the study, pelagic degradation products such as fecal pellets appear to be more important during the later part of the bloom period. The enrichment of detrital material in aggregates indicates that, in comparison to other components, it is preferentially subjected to aggregation. This may be attributed to a relatively higher stickiness. Mutual flocculation of phytoplankton and detritus or lithogenic debris such as clay, particularly during phytoplankton blooms as observed herein, further enhances sedimentation (Avnimelech et al. 1982). In fact, mass sedimentation of spring diatom blooms may effectively sweep the water column of suspended matter resulting in a pelagic spring cleaning' (Smetacek 1985).

A high enrichment of microorganisms in marine snow aggregates relative to the surrounding water was reported by many investigators (e.g. Silver et al. 1978, Prezelin \& Alldredge 1983, Trent 1985, Beers et al. 1986, Caron et al. 1986, Davoll \& Silver 1986). Concentrations of phytoplankton are commonly 1 to 3 orders of magnitude higher in aggregates than in the surrounding water (Alldredge \& Silver 1988). The highest enrichment factors during this investigation were found for diatoms (Table 2). Compared to diatoms, Phaeocystis sp. showed a relatively low enrichment in aggregates. Wassmann et al. (1990) suggested that during mass sedimentation of Phaeocystis pouchetii in the Barents Sea, aggregate formation of aged colonies was an important mechanism for enhancing vertical flux. While the disappearance of the Phaeocystis bloom observed at the fixed station during the early phase of this study was due to horizontal advection, high concentrations of Phaeocystis were recorded in the bottom 2 to $3 \mathrm{~m}$ of the water column during an $\mathrm{E}-\mathrm{W}$ transect between Helgoland Island and the coast of northern Germany (Riebesell unpubl.). Diver-collected samples taken from this highly-enriched bottom layer revealed that most Phaeocystis colonies were not associated with particle aggregates.

In combining kinetic coagulation theory with algal growth rates, Jackson (1990) developed a model describing the formation of algal aggregates during a phytoplankton bloom. By applying the data obtained during this investigation to Jackson's physical coagulation model, a comparison can be made between the in situ observations and model predictions. According to the model, at a critical maximum biomass concentration $\left(C_{\mathrm{cr}}\right)$ the rate of coagulation becomes predominant. This was the situation observed in this field study, since the maximum phytoplankton concentration coincided with the peak in total aggregate volume (see Riebesell 1991). Considering the first and crucial step in particle coagulation only, in which 2 single algal units interact, yields the simplified particle dynamics equation (Jackson 1990)

$$
\partial C_{1} / \partial t=\mu C_{1}-2 \alpha \beta C_{1}^{2}
$$

where $C_{1}=$ concentration of particles containing 1 algal unit; $\mu=$ specific growth rate of the algae; $\alpha=$ particle stickiness; $\beta=$ sum of terms describing the particle collision rate. For the initial step of coagulation in a monospecific bloom, differential settlement equals zero, therefore shear remains the only mechanism bringing particles in contact. This reduces the coagulation kernel $\beta$ to $\beta=10.4 \gamma_{T_{1}}{ }^{3}$, where $\gamma=$ shear rate and $r_{1}=$ radius of single algal units. The algal population stops expanding when cell growth is balanced by loss due to coagulation and sedimentation, resulting in $\partial C / \partial t=0$ and implying that the maximum, critical concentration $\left(C_{c r}\right)$ is given by

$$
C_{c r}=(0.048) \mu(\alpha \gamma)^{-1} r_{1}^{-3}
$$

Assuming algal growth rate $\mu=1.0$ div. $\mathrm{d}^{-1}$ (Eppley 1972), particle stickiness $\alpha=10^{-1}$ (Kiørboe 1990), and the mean shear rate $\gamma=0.37 \mathrm{~s}^{-1}$ (as estimated for the upper mixed layer; Riebesell 1991) leaves the particle radius $\left(I_{1}\right)$ as the only unknown variable required to solve Eq. (2). Since particle radius in Eqs. (1) and (2) is raised to the third power, the outcome of the model is very sensitive to even small differences in $r_{1}$. This led Jackson (1990) to emphasize the importance of measur- 
ing algal sizes when studying floc formation. Using a particle radius of $1.05 \times 10^{-3} \mathrm{~cm}$ (estimated from the mean cell volume of the dominant diatoms present at the peak of the bloom multiplied by 8 , based on an average chain-length of 8 cells) the critical concentration $C_{c r} \approx 1.30 \times 10^{4}$ cells $\mathrm{cm}^{-3}$ This is more than an order of magnitude larger than the maximum diatom concentration of 1020 cells $\mathrm{cm}^{-3}$ actually recorded during this study. A number of reasons could be responsible for this difference. Jackson's (1990) model describes a monospecific bloom, where differential settling is unimportant initially. Since the bloom observed in this field investigation consisted of many species, differential settling can be significant, in which case collision rate increases and the critical concentration decreases. However, even for a monospecific bloom, Eq. (2) overestimates $C_{c r}$ (see Jackson 1990). In addition, as in most diatom blooms, the algal community observed here was dominated by chain-forming species. Depending on the cell configuration in a diatom chain, its effective size can be much larger than the sum of the cell volumes. The above calculation therefore underestimates the effective particle radius. In order to predict the observed critical concentration of 1020 cells $\mathrm{cm}^{-3}$ from Eq. (2), a value of $2.45 \times 10^{-3} \mathrm{~cm}$ for the particle radius would have to be assumed. This could be a reasonable estimate for some of the chainforming species dominating during this study. The starlike chains of Thalassionema nitzschioides and Asterionella glacialis (Fig. 5b, c) are 2 examples of significant size enlargements due to cell configuration. However, the above assessment shows that in a phytoplankton population containing chain-forming species, a correct estimate for the effective size is extremely difficult to obtain, even if cell size and chain length are carefully measured.

In addition to chain configurations, protuberances such as silica spines, chitan microfibrils, or gelatinous threads can further increase the effective size. Ultimately, the enlargement of body size by chain-formation, chain configuration, and cell protuberances could have a drastic effect on the rate of algal coagulation. In addition to increasing body size, protuberances also enhance the probability for entanglement of algal cells (morphological stickiness), which further facilitates algal aggregation. The widespread presence of such protuberances in many bloom-forming diatoms suggests that enhancing aggregation could be advantageous in the life cycle of these species (Smetacek 1985). The high probability for entanglement in spine-bearing diatoms such as Chaetoceros, led Alldredge \& Gotschalk (1989) to suggest that the presence of setose genera may be necessary for the flocculation of diatom blooms. Although the dominant species found during this study were non-setose, the configuration of their cell chains (e.g. in Thalassionema nitzschioides and Asterionella glacialis) may well have the same effect.

The combined effects of chain-formation, enlargement of effective cell size, and morphological and physiological stickiness on algal aggregation were reflected in the distinct patterns of species-specific aggregation presented in Fig. 3. A high rate of aggregation due to the large effective size of chain-forming species is suggested by the relative enrichment of Asterionella glacialis, Thalassionema nitzschioides, and Skeletonema costatum in aggregates. As indicated by enrichment factors far greater than 1, the relative abundance of these species was consistently higher in aggregates than in the water column. In addition to chain-formation, the star-like configuration of chains of A. glacialis and T. nitzschioides, which increases both the effective size and the morphological stickiness, further enhanced aggregation. Enrichment factors of the solitary pennate diatom Nitzschia sp., on the other hand, were always below 1 , indicating that this species was consistently relatively less abundant in aggregates than in the water column. While this observation is in agreement with physical coagulation theory, which predicts a low collision rate for small and solitary cells, it is nevertheless unexpected as pennate diatoms are able to actively adhere to surfaces. This can greatly enhance their rate of aggregation. In fact, $N$. longissima and $N$. closterium were the dominant algae in large amorphous aggregates found in the Adriatic Sea (Revelante \& Gilmartin in press). However, as suggested by the authors, the high enrichment of these pennate diatoms in aggregates could be related to the fact that they were embedded in a gelatinous aggregate matrix early in the phytoplankton succession and maintained their growth within these aggregates. The high enrichment of the genus Coscinodiscus, also solitary, can on the one hand be related to its very large cell size and consequently high rate of collision. On the other hand, production of large amounts of mucilage, as reported for C. nobilis (Boalch \& Harbour 1977), may have enhanced cell stickiness resulting in an increase in the rate of coagulation.

Physiological stickiness, in addition to structural factors such as cell size, shape, and chain-formation, represents an effective means by which algal cells can influence the probability of coagulation. Enhanced cell stickiness could also be responsible for the observed increase in relative enrichment in aggregates (Fig. 3). For the 5 species presented, the rapid increase in aggregate enrichment coincided with their maximum cell abundance in the water column. Shortly after their peak enrichment in aggregates, each of these species almost completely disappeared from the phytoplankton community. Increased stickiness and subsequent flocculation at the end of the growth period has been 
considered to be a life cycle strategy of diatoms (Smetacek 1985), and could be demonstrated experimentally for the diatom Thalassiosira pseudonana (Kiorboe et al. 1990). Once flocculated into aggregates, enhanced sedimentation rapidly removed the algae from the upper mixed layer (cf. Fig. 3).

Smetacek (1985) and Logan \& Alldredge (1989) suggested that increased stickiness is related to nutrient depletion after phytoplankton blooms. None of the macronutrients became exhausted during the period of investigation (Fig. 1), although a rapid decline in both nitrate and silica concentrations occurred during the development of the bloom and immediately before the period of maximum aggregation. Subsequent to the bloom peak, the silica concentration remained below $1.5 \mu \mathrm{M}$, which may be limiting to diatom growth (Paasche 1980). The lowest silica concentration recorded during this study $(0.62 \mu \mathrm{M}$ on 19 May), coincided with the maximum aggregate size (Fig. 5; Riebesell 1991). While these large (>10 $\mathrm{mm}$ diameter) aggregates occurred at a time when both the phytoplankton biomass and the amount of aggregated material had decreased to less than $25 \%$ of their respective peak values, their formation could be related to the release of exopolymers by phytoplankton, which commonly takes place during the decline of blooms (Degens \& Ittekkot 1984). The release of exopolymers by phytoplankton may also be responsible for the rapid increase in stickiness (Smetacek 1985).

A distinct relationship between the species succession in the water column and in aggregates was observed over the course of the bloom. This is indicated by the patterns in cell abundance and aggregate enrichment of the 5 different species (Fig. 3). The first species to reach its peak abundance in the water column (Skeletonema costatum), for example, is also the first species to become enriched in aggregates. Similarly, the last species to peak (Asterionella glacialis, Thalassionema nitzschioides) are also the last ones to accumulate in aggregates. This indicates that diatom flocculation is a process which not necessarily involves the entire diatom community simultaneously, but which can successively affect individual species. The variation in physiological stickiness linked to the specific life cycle of each species could induce such a succession in aggregates. On the other hand, repetitive cell division in chain-forming diatoms results in increased chain length, implying that the observed species succession in aggregates could simply reflect the average chain length of a species at the time of aggregation. The species which dominates early in the bloom would be the first to form long cell chains and, due to the strong dependency of physical coagulation on particle size as discussed above, would be preferen- tially subjected to aggregation and subsequent sedimentation. Differences in the rate and timing of species-specific sedimentation was also observed by Riebesell (1989). Thus, in a community of chain-forming diatoms, physical coagulation could induce species succession.

In summary, aggregation processes are strongly influenced by factors such as the effective size of algal cells, and the physiological as well as morphological stickiness of the algae. While the specific combination of physical conditions in a system defines the boundaries within which coagulation processes may occur, biological factors determine the ultimate course of particle aggregation during algal blooms. Vice versa, coagulation processes can have a significant impact on phytoplankton ecology, in particular on phytoplankton species succession. An important goal in future research will be to obtain a better understanding of the biological mechanisms influencing particle aggregation and to incorporate biological variability into physical coagulation models.

Acknowledgements. The continuous support of the department for guest research of the Biologische Anstalt Helgoland (BAH), where the field investigation was carried out, and of $U$. Schilling and the BAH diving group, are gratefully acknowledged. I thank P. C. Abreu, I. Bock, and H. Reichenberger for diving assistance, and S. Ehlken, J. Höhlemann, E.-M. Nöthig, and $C$. Schenk for technical support in the field. Special thanks go to $\mathrm{H}$. Candia for help in phytoplankton and bacterial enumeration. Measurements of inorganic nutrients were kindly provided by $G$. Kattner and coworkers. Thanks also go to captain and crew of RV 'Aade', 'Diker', and 'Uthörn' of the BAH. P. C. Abreu, U. Bathmann, B. Biddanda, M. Botros, V Smetacek and 3 anonymous reviewers provided valuable comments to the manuscript. Publication No. 379 of the Alfred Wegener Institute for Polar and Marine Research.

\section{LITERATURE CITED}

Alldredge, A. L., Gotschalk, C. C. (1989). Direct observations of the mass flocculation of diatom blooms: characteristics. settling velocities and formation of diatom aggregates. Deep Sea Res. 36 (2): 159-171

Alldredge, A. L., Silver, M. W. (1988). Characteristics, dynamics and significance of marine snow. Prog. Oceanogr. 20: 41-82

Avnimelech, Y., Troeger, B. W., Reed, L. W (1982). Mutua! flocculation of algae and clay: evidence and implications. Science 216: 63-65

Beers, J. R., Trent, J. D., Reid, F. M. H., Shanks, A. L. (1986). Macroaggregates and their phytoplanktonic components in the Southern California Bight. J. Plankton Res. 8: $475-487$

Biddanda, B. A. (1985). Microbial synthesis of macroparticulate matter. Mar. Ecol. Prog. Ser. 20: 241-251

Boalch, G., Harbour, D. S. (1977). Unusual diatom off the coast of south-west England and its effect on fishing. Nature, Lond. 269: 687-688

Bodungen, B. von, Smetacek, V S., Tilzer, M. M., Zeitzschel, 
B. (1986). Primary production and sedimentation during spring in the Antarctic Peninsula region. Deep Sea Res. 33 (2): $177-194$

Caron, D. A., Davis, P. G., Madin, L. P., Sieburth, J. M. (1986). Enrichment of microbial populations in macroaggregates (marine snow) from surface waters of the North Atlantic. J. mar Res. 44: 543-565

Davoll, P. J., Silver, M. W. (1986). Marine snow aggregates: lufe history sequence and microbial community of abandoned larvacean houses from Monterey Bay. California. Mar Ecol. Prog. Ser. 33: 111-120

Degens, E. T., Ittekkot, V. (1984). A new look at clay-organic interactions. Mitt. Geol.-Paläont. Inst. Univ. Hamburg 56: $229-248$

Eppley, R. W. (1972). Temperature and phytoplankton growth in the sea. Fish. Bull. U.S. 70: 1063-1085

Hobbie, J. E. Daley, R. J., Jasper, S. (1977). Use of nuclepore filters for counting bacteria by fluorescence microscopy. Appl. environ. Microbiol. 33: 1225-1228

Jackson, G. A. (1990). A model of the formation of marine algal flocs by physical coagulation processes. Deep Sea Res. 37 (8): 1197-1211

Kepkay, P. E., Johnson, B. D. (1988). Microbial response to organic particle generation by surface coagulation in seawater. Mar Ecol. Prog. Ser. 48: 193-198

Kiorboe, T., Andersen, K. P., Dam, H. G. (1990). Coagulation efficiency and aggregate formation in marine phytoplankton. Mar Biol. 107: 235-245

Kranck, K., Milligan, T (1980). Macroflocs: production of marine snow in the laboratory. Mar Ecol. Prog. Ser 3: $19-24$

Kranck, K. Milligan, T (1988). Macroflocs from diatoms: in situ photography of particles in Bedford Basin, Nova Scotia. Mar. Ecol. Prog. Ser. 44: 183-189

Logan, B. E., Alldredge, A. L. (1989). Potential for increased nutrient uptake by flocculating diatoms. Mar. Biol. 101: $443-450$

Paasche, E. (1980). Silicon. In: Morris, I. (ed.) The physiological ecology of phytoplankton. Blackwell, Oxford p. $259-284$

Parsons, T R., Maita, Y., Lalli, C. M. (1984). A manual of

This article was submitted to the editor chemical and biological methods for seawater analysis. Pergamon Press, New York

Peinert, R., Saure, A., Stegmann, P., Stienen, C., Haardt, H., Smetacek, V (1982). Dynamics of primary production and sedimentation in a coastal ecosystem. Neth. J. Sea Res. 16: 276-289

Prezelin, B. B., Alldredge, A. L. (1983). Primary production of marine snow during and after an upwelling event. Limnol. Oceanogr 28: 1156-1167

Radach, G., Berg, J., Hagmeier, E. (1990). Long-term changes of the annual cycles of meteorological, hydrographic, nutrient and phytoplankton time series at Helgoland and at LV ELBE 1 in the German Bight. Cont. Shelf Res. 10 (4): 305-328

Revelante, N., Gilmartin, M. (in press). The phytoplankton composition and population enrichment in gelatinous 'macroaggregates' in the northern Adriatic Sea during the summer of 1989. J. exp. mar. Biol Ecol.

Riebesell, U. (1989). Comparison of sinking and sedimentation rate measurements in a diatom winter/spring bloom. Mar. Ecol. Prog. Ser. 54: 109-119

Riebesell, U. (1991). Particle aggregation during a diatom bloom. I. Physical aspects. Mar. Ecol. Prog. Ser. 69: 273-280

Silver, M. W., Shanks, A. L., Trent, J. D. (1978). Marine snow: microplankton habitat and source of small-scale patchiness in pelagic populations. Science 201: 371-373

Smetacek, V S. (1985). Role of sinking in diatom life-history cycles: ecological, evolutionary and geological significance. Mar. Biol. 84: 239-251

Smetacek, V., Pollehne, F. (1986). Nutrient cycling in pelagic systems: a reappraisal of the conceptual framework. Ophelia 26: 401-428

Trent, J. D. (1985). A study of macroaggregates in the marine environment. Ph.D. thesis, Scripps Institution of Oceanography, University of California, San Diego

Utermöhl, H. (1958). Zur Vervollkommnung der quantitativen Phytoplankton-Methodik. Mitt. int. Verein theor. angew. Limnol. 9: 1-38

Wassmann, P., Vernet, M., Mitchell, B. G., Rey, F. (1990). Mass sedimentation of Phaeocystis pouchetij in the Barents Sea. Mar. Ecol. Prog. Ser 66: 183-195

Manuscript first received: August 24, 1990

Revised version accepted: November 26, 1990 